\title{
VIDEO BASED LEARNING SEBAGAI TREN MEDIA PEMBELAJARAN DI ERA 4.0
}

\author{
Hesty Maulida Eka Putry, Venia Nuzulul ‘Adila, \\ Rofiatus Sholeha, Danial Hilmi ${ }^{*}$ \\ 1Pascasarjana UIN Maulana Malik Ibrahim Malang
}

\begin{abstract}
This paper is a literature review related to video based learning as a learning media trend in the 4.0 era. Issues that will be discussed in this paper include; industrial revolution, educational revolution, media trends in the 4.0 era, to video based learning. Data collection methods by collecting library data, reading and recording, and processing literacy materials related to these issues. Because the media is one system that plays an important role in the development of learners to increase innovative and effective knowledge. This discussion emphasizes video media as a learning tool that can help students in rationally illustrating material Arabic learning is difficult learning for students, with the existence of video media that is trending in the 4.0 era this will help students in the learning process, learning Arabic using media video makes students easy to understand the content of the lesson with clear illustrations without making students to illustrate abstractly, then the presence of video media as a means of learning Arabic will make it easier for students to understand the content of the material provided by the teacher.
\end{abstract}

\section{Keywords: Video, Learning, Media, 4.0 Era}

Abstrak: Tulisan ini merupakan kajian literatur terkait video based
learning sebagai tren media pembelajaran pada era 4.0. Isu-isu yang
akan dibahas pada tulisan ini diantaranya; revolusi industri, revolusi
pendidikan, tren media pada era 4.0, hingga video based learning.
Metode pengumpulan data dengan mengumpulkan data pustaka,
membaca dan mencatat, serta mengolah bahan literasiyang terkait
dengan isu-isu tersebut.karena media merupakan salah satu sistem
yang berperan penting dalam perkembangan peserta didik untuk

*Korespondensi Penulis: ekaputry142@gmail.com 
meningkatkan pengetahuan yang inovatif dan efektif. Pembahasan ini menekankan pada media video sebagai sarana pembelajaran yang dapat membantu siswa dalam mengilustrasikan materi secara rasional pembelajaran bahasa Arab merupakan pembelajaran yang sulit bagi siswa, dengan adanya media video yang tren di era 4.0 ini akan membantu siswa dalam proses pembelajarannya, pembelajaran bahasa Arab menggunakan media video membuat siswa untuk mudah memahami konten pelajaran dengan bentuk ilustrasi yang jelas tanpa membuat siswa untuk mengilustrasikan secara abstrak, maka dengan adanya media video sebagai sarana pembelajaran bahasa Arab akan memudahkan siswa untuk memahami konten materi yang diberikan oleh guru.

\section{Kata Kunci: Video, Learning, Media, Era 4.0}

\section{A. Pendahuluan}

Media pembelajaran sangatlah mempengaruhi proses pembelajaran. Seiring berkembangnya zaman, terjadi revolusi industri dan revolusi pendidikan sepanjang sejarah. Terjadinya revolusi pada kedua bidang ini tentunya memiliki keterkaitan satu sama lain dan memberi dampak kehidupan manusia. Revolusi industri memengaruhi terjadinya revolusi pendidikan. Berkembangnya teknologi menjadi tantangan bagi para pengajar untuk bisa memanfaatkan sebaik mungkin teknologi yang ada. Salah satu pemanfaatan teknologi adalah pada media pembelajaran.

Revolusi industri sudah sampai pada era 4.0, Revolusi industri ini di tandai dengan adanya teknologi baru yang mana terdapat kolaborasi antara peratan fisik atau digital dengan Mobile Technology, Internet of Things untuk membantu perkembangan manusia, unnamed vehicle, artificial intelligence, big data dan fasilitas produksi baik berupa pengumpulan data dan analisis secara manual atau otomatis. Bersamaan dengan itu, revolusi pendidikan juga tengah berada pada era 4.0. Hal tersebut ditandai dengan sistem pembelajaran yang mandiri dan berpusat pada peserta didik. Dampak dari adanya revolusi ini adalah penggunaan teknologi sebagai media pembelajaran. Tren media pembelajaran pada era 4.0 diantaranya 
pembelajaran berbasis audio, pembelajaran berbasis video, pembelajaran berbasis gambar atau ilustrasi, pembelajaran berbasis web, pembelajaran berbasis mobile hingga pembelajaran yang memadukan diantara beberapa model tersebut atau lebih dikenal dengan blended learning. Pada tulisan ini akan membahas terkait pembelajaran berbasis video atau video based learning sebagai tren media pembelajaran di era 4.0.

Sebagai tren media pembelajaran, sejumlah besar akademisi publikasi telah menyelidiki dan menganalisis VBL dari perspektif yang berbeda. Yousef melakukan peer review terhadap 76 makalah melalui jurnal dan database akademik yang terbit dalam kurun waktu 2003 sampai 2014 1. Pendekatan pemetaan kognitif digunakan untuk memetakan penelitian yang dilakukan pada VBL menjadi empat dimensi utama yaitu, efektivitas, metode pengajaran, desain, dan refleksi. Sebagian besar studi VBL yang ditinjau masih mengikuti pendekatan pembelajaran konvensional di mana guru adalah pusat dari proses pembelajaran. Selain itu, ada fokus pada metode penilaian tradisional, seperti e-Tes dan kuis.

Hingga saat ini, riset, kajian dan studi literatur terkait video based learning masih marak dilakukan oleh para akademisi. Penerapan video based learning sangat relevan dengan proses pembelajaran pada zaman ini yang didominasi oleh generasi millenial dan generasi Z. Oleh karena itu, tulisan ini hendak menghadirkan sebuah studi literatur yang membahas video based learning sebagai tren media pembelajaran di era 4.0.

\section{B. Metode Penelitian}

Penelitian ini menggunakan metode kajian literatur, yang berupa serangkaian kegiatan yang berkenaan dengan metode pengumpulan data kepustakaan, menelaah dan mencatat, serta mengkaji bahan penelitian.Studi kepustakaan ini dilakukan oleh penulis yang bertujuan untuk mencari dasar

\footnotetext{
${ }^{1}$ Ahmed Mohamed Fahmy Yousef, Mohamed Amine Chatti, and Ulrik Schroeder, 'The State of Video-Based Learning: A Review and Future Perspectives', Int. J. Adv. Life Sci, 6.3/4 (2014), 122-135.
} 
pijakan untuk memperoleh landasan teori, kerangka berpikir, memberikan suatu gambaran hal-hal yang telah diketahui dan yang belum diketahui dari suatu fenomena khusus dan mengidentifikasi dari hasil-hasil penelitian terdulu. (Afiyanti 2005:32)

Penulis menggunakan literatur dari berbagai artikel ilmiah. Adapun berikut langkah-langkah studi literatur menurut ( Nazir, 2005: 62-63) adalah sebagai berikut: 1) Pengumpulan data; data yang digunakan dalam metode ini merupakan data sekunder, data sekunder adalah data pendukung yang bersumber dari literature dan referensi yang berasal dari artikel ilmiah atau buku. 2) Pengolahan dan Analisis data; Pengelolaan data dalam metode ini bertujuan untuk mempermudah dalam menganalisis data, teknik analisis yang gunakan berupa penyajian data dan reduksi data. Kemudian langkah selanjutnya menyusun metodologi penulisan dari hasil studi literature sehingga dapat menarik kesimpulan yang di dapatkan.

\section{Hasil Pembahasan}

\section{Revolusi Industri Dalam Pendidikan}

Sepanjang sejarah peradaban, revolusi terjadi ketika adanya teknologi baru beserta cara baru untuk memahami dunia sehingga menyebabkan perubahan besar dalam sistem ekonomi dan struktur sosial. Istilah tersebut dikenal dengan revolusi Industri, revolusi industri memiliki hubungan dengan berbagai macam perubahan yang fundamental pada beberapa bidang industri termasuk pertanian, pertambangan, manufaktur, teknologi dan transportasi. Perubahan pada beberapa bidang kehidupan tersebut juga memberi dampak pada perkembangan pendidikan. Hal tersebut menjadi tantangan bagi para pendidik untuk menyesuaikan kebutuhan pembelajaran dengan kemajuan industri teknologi, informasi dan komunikasi.

Revolusi industri pertama terjadi pada tahun 1750-1870, dengan adanya mekanisasi produksi yang menyokong efektivitas dan efisiensi kegiatan manusia, 
yaitu dengan adanya perubahan dari pembuatan barang yang dapat dihasilkan dengan tangan kemudian beralih ke pemanfaatan mesin. Revolusi industri $1.0 \mathrm{ini}$ ditandai dengan penemuan mesin uap pada tahun 1784 dan kereta api pertama pada tahun 1804. Fasilitas produksi mekanis bertenaga air dan uap mendorong perkembangan pada bidang industri.Penemuan-penemuan tersebut mulai menggantikan tenaga manusia, sebagai upaya meningkatkan produktivitas yang bernilai tinggi kala itu.

Revolusi industri selanjutnya 2.0 berlangsung pada tahun 1870-1971, pada fase ini pun terjadi produksi massal dan jalur perakitan yang ditandai dengan ditemukannya pembangkit listrik, motor berbahan bakar, telegraf, telepon, pesawat terbang, kereta api, gas dan lainnya yang mengakibatkan transportasi dan komunikasi dapat dimanfaatkan secara tepat ${ }^{2}$. Kondisi ini memunculkan pergerakan manusia dan informasi yang tidak sama lagi dengan masa sebelumnya. Yang terpenting pada masa ini adalah menjai penyebab produksi barang seperti pupuk, minyak bumi dan mobil. 3 .

Sementara revolusi industri 3.0 berlangsung pada tahun 1971-2010. Menurut Hermann, era industri 3.0 dikenal karena penyesuaian massa, fleksibilitas otomatisasi dan manufaktur berbasis robot ${ }^{4}$.Selain itu, adanya penemuan komputer, elektronik digital, dan juga internet. Aplikasi memory programmable controls (aplikasi kontrol memori yang dapat diprogram) yang terkandung di dalamnya untuk memungkinkan dalam pembuatan robot (mesin yang dapat bekerja secara otomatis).

Sedangkan revolusi industri keempat dimulai setelah 2010, yang dinamakan dengan revolusi industri 4.0 dan ditandai dengan kolaborasi antara

${ }^{2}$ Parlindungan Pardede.. Menjadi Guru "Zaman Now" dan Cara Pembelajaran Siswa Memasuki Era Industri 4.0. Makalah dipresentasikan dalam Seminar Nasional FKIP Parlindungan Pardede (2020). Hlm. 20.

${ }^{3}$ Eka Ramadhani Siregar. Multimedia Pembelajaran Dalam Era Revolusi Industri 4.0. (2018). Diakses tanggal 16 Mei 2020 pada http://catatankimmunika.blogspot.com

${ }^{4}$ Kurnia Martikasari, Kahoot: Media Pembelajaran Interaktif Dalam Era Revolusi Industri 4.0. Makalah dipresentasikan pada Seminar Nasional FKIP 2018 
peralatan fisik dan MT (teknologi mobile), IoT (internet of things), UV (kendaraan tanpa nama), AI (kecerdasan buatan), Big data, dan fasilitas produksi sehingga menjadikan proses produksi, baik berupa pengumpulan data maupun analisis dan pengambilan keputusan dilakukan secara manual dan otomatis.Pada tahun 2011, Hannover Fair menciptakan istilah industri 4.0 untuk menggambarkan bagaimana merevolusi organisasi dalam rantai global. Revolusi industri 4.0 mewujudkan sebuah dunia gabungan sistem fisik dan virtual dengan didirikannya "pabrik pintar". Dunia ini memungkinkan perusahaan untuk saling bekerja sama secara global dan secara luwes dan memungkinkan kustomisasi produk lengkap dan menciptakan model operasi baru 5

\section{Revolusi Pendidikan Melalui Perkembangan Teknologi}

Revolusi tidak hanya terjadi pada bidang industri saja, pendidikan pun mengalami revolusi seiring berkembangnya industri tersebut. Pendidikan pada zaman kuno ke abad pertengahan merupakan pendidikan pribadi yang terbatas pada beberapa peserta didik, keterampilan untuk otot, rendahnya tingkat melek huruf dan metode pendidikan informal. Selanjutnya konsep pendidikan formal pemimpin-pemimpin gereja mulai memunculkan dan mengembangkan konsep pendidikan di gereja.

Revolusi pendidikan 1.0 ditandai dengan pendirian universitas meskipun belum ada sistem kurikulum, assessment dan pengakuan resmi. Pendidikan 1.0 ini bertipe essensialis dengan pendekatan behaviorisme yang didasarkan pada 3R yaitu Receiving (menerima)berarti menerima penjelasan guru, Responding dengan cara mencatat lalu mengkaji teks dan Regurgittating (memuntahkan)

\footnotetext{
${ }^{5}$ Toto Nusantara. Desain Pembelajaran 4.0. Makalah dipresentasi dan dipublikasikan dalam Prosiding Seminar Nasional Lembaga Penelitian Dan Pendidikan (LPP) Mandala. (2018)
} 
dengan memberikan asesmen yang sama ${ }^{6}$. Sistem pendidikan dengan proses satu arah tersebut mengakibatkan perkembangan di bidang pendidikan menjadi sangat lambat.

Pada pertengahan abad ke-15, Revolusi pendidikan 2.0 dipacu dengan ada temuan mesin cetak dan hal tersebut memberi perubahan besar pada sektor pendidikan dan mampu mengatasi tingkat melek huruf dengan penyebaran gagasan secara cepat melalui buku. Selanjutnya masa ini juga didukung dengan terjadinya revolusi ilmiah, renaissance dan reformasi yang mengembangkan rasa keingin tahuan masyarakat, ide-ide baru dan mendorong adanya inovasi. Pada masa ini pula orientasi pengajaran lebih kontruktivis dengan prinsip pengalaman terhadap belajar yang aktif, relevan, otentik dan membangun jaringan sosial.

Peralihan dari pendidikan 2.0 menuju pendidikan 3.0 sekitar awal tahun 1970an ditandai dengan adanya internet dan IT yang menyediakan platform teknologi sebagai wadah untuk belajar. Pada periode ini terjadi peningkatan pendidikan secara signifikan ditandai dengan meningkatnya aksesibilitas belajar di perguruan tinggi. Dengan meningkatnya permintaan global untuk pendidikan, mengubah peran guru yang mulanya hanya menjadi instruktur berubah menjadi fasilitator dan keberadaan teknologi sebagai penyalur pengiriman bahan ajar di berbagai pembelajaran online maupun jarak jauh.

Peralihan pendidikan 3.0 menuju pendidikan 4.0 sangat cepat berlangsung dengan ditunjang dengan smartphone, perkembangan teknologi IT, internet dan social media. Fokus pendidikan 4.0 adalah pada peserta didik, diperagakan oleh peserta didik dan dipandu oleh peserta didik. Dengan desain yang menjadikan peserta didik sebagai puast pembelajaran, internet dengan jaringan tinggi menawarkan lingkungan yang mendukung pendekatan heutagogical (pembelajaran yang berpusat pada pembelajar), yang utama dengan

\footnotetext{
${ }^{6}$ Toto Nusantara. Desain Pembelajaran 4.0. Makalah dipresentasi dan dipublikasikan dalam Prosiding Seminar Nasional Lembaga Penelitian Dan Pendidikan (LPP) Mandala. (2018)
} 
mendukung pengembangan bahan ajar yang dihasilkan oleh peserta didik dan diri peserta didik.

Dengan terjadinya revolusi industri yang berdampak pada revolusi pendidikan, maka kehadiran media pembelajaran yang sesuai dengan perkembangan tersebut sangatlah dibutuhkan. Media pembelajaran yang memadai tentunya akan memudahkan proses pembelajaran dan meningkatkan motivasi belajar para pembelajar. Pada studi literatur ini, kami mencoba menghadirkan beberapa karakteristik dan tren media pembelajaran pada era 4.0 ini.

\section{Karakteristik Media Pembelajaran Di Era 4.0}

Revolusi industri merupakan integrasi antara teknologi cyber dan otomatisasi, perubahan revolusi industri dari tenaga manusia menjadi industri digital. Dampak revolusi industri 4.0 terdapat beberapa karakteristik sebagai unsur utama dalam mengembangkan industri di era 3.0 menuju industri 4.0, diantaranya :

a. Internet of Things (IoT), jaringan internet sebagai koneksi dalam mentransfer data tanpa batuan manusia.

b. Big data, Banyak informasi data yang telah input secara manual atau otomatis akan tersensor dan masuk dalam sistem sebuah data.

c. Argumented reality, mengkolaborasikan benda maya 2D atau 3D dan memproyeksikan dalam waktu nyata.

d. Cyber security, mengamankan sebuah informasi untuk mencegah cyberattack.

e. Artifical manufacturing, yang biasa disebut AI merupakan mesin pintar yang memiliki kecerdasan mirip manusia, dalam hal ini mampu menganalisis data secara berkesinangmbungan dan dapat diterima.

f. System integeration, menghubungkan sistem dengan software secara fisik dan fungsional. 
g. Cloud computing adalah teknologi penyimpanan data yang menggunakan internet untuk mengakses program tanpa instalasi7.

Era Revolusi Industri ini terdiri dari cyber physical systems, internet of things dan networks. Istilah industri 4.0 merupakan salah satu proyek inisiatif pemerintah Jerman untuk mempromosikan manufaktur yang terkomputerisasi.Melalui hal ini maka Revolusi Industri 4.0 telah menggembangkan sesuatu hal yang diluar nalar, dengan dibekalinya keterampilan atau kompetensi 4cs yang meliputi: Critical thinking, Communication, Colaborative dan Creative. Keempat kompetensi yang melahirkan pembelaran yang inovatif bagi pendidikan.Sehingga media yang digunakan sebagai sarana pengembangan potensi peserta didik dapat digunakan secara efektif dan efisien. Dalam perubahan menuju era 4.0 terdapat prinsip yang menandainya, diantaranya ${ }^{8}$

a. Bantuan teknis: bisa berupa fisik maupun virtual

b. Interkoneksi: baik berupa standar, keamanan dan kolaborasi

c. Keputusan terdesentralisasi

d. Transparansi informasi: penyediaan informasi dan analisis data

Prinsip industri 4.0 merupakan perubahan sistem pergerakan manusia menjadikan sebuah pengoperasionalan secara koordinasi antara mesin dan manusia dengan perantara media yang berkembang di era ini. Implementasi industri 4.0 bisa melalui berbagai media pembelajarn konvensional dan menjadikannya media baru untuk mengembangkan kualitas penggunaan dan manfaat dalam menerapkannya di era revolusi industri 4.0, seperti yang telah terjadi di era digital ini, penggunaan gadget merupakan salah satu sarana yang sering digunakan oleh kalangan masyarakat indonesia, sehingga penggunaan

${ }^{7}$ Kevin Olla. Era Revolusi Industri 4.0 : Semua Hal Yang Perlu Kamu Ketahui. Blog Jagoan Hosting / Tutorial Website \& Web Hosting Indonesia. (2019). Diakses tanggal 20 Mei 2020 pada https://www.jagoanhosting.com

${ }^{8}$ Muhammad Yahya. Era Industri 4.0: Tantangan dan Peluang Perkembangan Pendidikan Kejuruan Indonesia. (2018). 
media pembelajaran bisa melalui perantara gadget atau secara digitalitasasi sebagai alat penghubung media pembelajaran konvensional menjadi media baru atau perkembangan inovasi media pembelajaran. media yang berkembang di era ini dinamakan media interaktif yang merupakan interaksi antara guru dan murid secara aktif dengan perantara media. Di era revolusi industri 4.0 ini pembelajaran berada dalam generasi milenial yang sejalan dengan kemajuan teknologi berbasis aplikasi, peserta didik lebih menyukai media yang menarik dalam belajar 9

Pada saat era revolusi industri 4.0 atau era disfusi, kegiatan pendidikan tidak dapat dibatasi dalam lingkup kelas saja, namun pendidikan di era digital ini sudah memasuki era yang mana pendidikan berkembang sesuai kebutuhan yang kompleks sehingga dapat menembus ruang dan waktu. Pemanfaatan era digitalisasi terdapat teknologi yang berkembang tanpa menjadikan hambatan dalam proses pembelajaran. salah satunya video based learning, pembelajaran berbasis video tidak tergantung dalam ruang dan waktu, dan bisa di atur sesuai kebutuhan dalam pembelajaran. penggunaan video sebagai media pembelajaran banyak di lakukan dalam berbagai kegiatan seperti seminat, diskusi dan sejenisnya.

Video based learning merupaakan metode yang berbasis video dalam penerapan pembelajaran di era 4.0, sehingga terdapat unsur-unsur dasar dalam pengembangannya menuju revolusi industri 4.0, pengembangan media video yang mulanya hanya sebatas digunakan dalam proses pembelajaran berupa materi di dalamnya, untuk media video di era 4.0 dapat diimplementasikan dengan penggunaan secara terbuka dan tidak terbatasi oleh ruang kelas bisa digunakan dimanapun dan kapanpun.

${ }^{9}$ Yuniani, Armelia, Dwi Irma Ardianti, and Wal Asri Rahmadani. Era Revolusi Industri 4.0: Peran Media Sosial Dalam Proses Pembelajaran Fisika di SMA. Gravitasi: Jurnal Pendidikan Fisika dan Sains. Vol 2 (1) 2019. Hlm. 18-24. 
Manfaat video sebagai media pembelajaran di era 4.0 sangat besar, seperti dalam pembelajaran bahasa asing yang banyak digandrungi oleh masyarakat sebagai alat komunikasi yang penting di era 4.0, maka video bisa digunakan sebagai perantara pembelajaran bahasa tersebut, seperti halnya pembelajaran bahasa Arab yang membutuhkan native speaker untuk penerapan bahasa atau belajar bahasa Arab dengan penutur asli sebagai bentuk pemahaman yang nyata maka dengan adanya video sebagai media pembelajaran bisa dijadikan jembatan dalam pembelajaran bahasa tersebut ${ }^{10}$.

Pembelajaran yang berbasis video bisa dilakukan ketika peserta didik dan guru tidak berada dalam ruang yang sama, penggunaan media ini menerapkan unsur dasar dalam revolusi industri 4.0 yang berupa Internet of Things (IoT), untuk menghubungkan interaksi antara peserta didik dan guru secara langsung tidak membutuhkan penghubung yang rumit namun dapat menghubungkan secara sederhana dengan adanya internet, merealisasikan pembelajaran yang efektif dan inovatif menggunakan video bisa menggunakan alat komputer atau smartphone. Kecanggihan teknologi dalam perkembangan pendidikan dalam hal ini menuntut guru atau peserta didik untuk meningkatkan kemampuan dalam memahami Ilmu Teknologi (IT) sehingga pembelajaran berrsifat aktif, kreatif dan inovatif 11.

\section{Tren Media Pembelajaran Di Era 4.0}

Dunia pendidikan yang kita alami sekarang ini, bertumbuh pesat dan mengalami kemajuan pasca pemanfaatan teknologi informasi dan komunikasi dalam bidang pendidikan.Era globalisasi pendidikan yang lebih menekankan kepada kreatifitas dan hubungan-hubungan antara manusia yang bernilai ekonomi tinngi menjadi lebih menonjol daripada intelektualis dalam bidang

\footnotetext{
${ }^{10}$ Abdul Muis Joenaidy. Konsep Dan Strategi Pembelajaran Di Era Revolusi Industri 4.0 (Yogyakarta: Laksana, 2019).

${ }^{11}$ Annisa' Rofifah Warohidah and Anggun Badu Kusuma, Perkembangan Era Revolusi Industri 4.0 Dalam Pembelajaran Matematika. 5.1 (2019)
} 
matematika dan sains.Fakta ini menunjukkan bahwa pendidikan dinamis bukan statis yang mengikuti perkembangan zaman dan peranan pendidikan untuk memajukan bangsa Indonesia yang terbukti dalam pembangunan ekonomi, sosial, budaya dan politik.

Pada era industry 4.0 ini seorang pendidik dapat menciptakan proses pembelajaran yang menarik, kreatif, inovarif dan menyenangkan, dengan memanfaatkan beberapa media yang trend saat ini untuk meraih tujuan dari proses pembelajaran. Begitu pula seorang peserta didik di era milenial ini, harus bisa memanfaatkan pembelajaran yang di sajikan oleh seorang guru, yang mana pembelajaran tersebut bisa dikatakan menarik, kreatif, inovatif dan menyenangkan.Karena dengan terpenuhnya kriteria pembelajaran tersebut dapat menjadikan dunia pembelajaran menjadi efektif dan berkembang dengan seiring zaman agar dapat menjawab tantangan di era milenial ini.

Pada hakikatnya kita sebagai peserta didik atau pun guru di era revolusi industri 4.0 sudah mengetahui beberapa media pembelajaran yang tren atau yang sudah terkenal dan mampu meningkatkan kualitas dalam pembelajaran, pada era ini peserta didik maupun guru dapat memanfaatkan teknologi informasi dan komunikasi sebagai sumber dan medium utama dalam pembelajaran. Ada beberapa media pembelajaran yang tren dan sering digunakan oleh peserta didik maupun guru, diantaranya, audio based learning, video based learning, website based leraning, mobile based learning, dan blanded learning.

Strategi dalam belajar, misalnya belajar bahasa arab di era milenial ini bisa menggunakan beberapa media pembelajaran yang tren atau yang sudah terkenal seperti yang telah di sebutkan diatas, contoh dalam pembelajaran bahasa arab dengan menggunakan audio visual, dapat melatih maharah istima' dengan sistem kita mendengarkan materi yang ada di audio visual dengan tenang dan teliti secara seksama sehingga kita dapat memahami materi tersebut dengan baik dan benar. 
Belajar melalui Video based learning seperti youtube misalnya, juga bisa menunjang dalam pembelajaran bahasa arab, misalnya mencari lagu-lagu arab fusha, bernyanyi dan bergembiralah, dengan itu peserta didik akan belajar bagaimana cara pengucapan bahasa arab fusha, selain itu ia mendapatkan kosa kata baru dalam bahasa arab.

Kemudian website based learing juga merupakan tren media pembelajaran pada era 4.0, website based learning bisa diterapkan dalam pembelajaran bahasa arab dengan menggunakan sistem one day one sentence dan one day one story. Bacalah berita-berita actual dalam bahasa arab melalui surat kabar digital atau elektronik seperti web aljazira dan al ahrom dan lainlain. Dari bacaan ini anda akan mendapatkan istilah-sitilah dan ungkapan baru yang sesuai dengan perkembangan zaman now.

Mobile based learning juga merupakan media pembelajaran yang paling mudah untuk dibawa kemanapun karena dengan bentuknya yang tidak terlalu besar dan ringan, oleh karena itu, kebanyakan semua orang yang ada didunia ini bisa di bilang lebih suka mengaplikasikan media mobile based learning, sehingga banyak orang yang menganggap bahwa media based learning merupakan media yang paling tren dan termudah.

Kemudian media blanded learning juga merupakan media yang paling tren di era 4.0, karena media ini bisa menjangkau pembelajaran face to face dalam jarak jauh. Dan semua tren media yang telah disebutkan di atas harus menggunakan internet, untuk mengaplikasikannya. Dengan adanya tren media pembelajaran 4.0 yang akan selalu berkembang nantinya, semua tren media pembelajaran ini bisa menjawab tantangan pembelajaran pada era revolusi 4.0.

Dari semua tren media pembelajaran yang telah disebutkan di atas, penulis akan membahas salah satu saja yaitu video based learning. Mulai dari membahas pengertian video based learning, sejarah penggunaan video sebagai media pembelajaran, manfaat, tujuan hingga kelebihan dan kekurangan dari video based learning. 


\section{Video Based Learning}

Istilah video based learningdigunakan dalam pembelajaran untuk mendesain pengetahuan atau keterampilan yang diperoleh dengan diajarkan melalui video. Video dalam hal ini terdapat dua elemen yaitu audio dan visual, audio digunakan sebagai menguraikan informasi secara lisan sedangkan visual sebagai menyediakan sumber utama atau pemaparan isi secara tulisan atau gambar.

Media video adalah salah satu jenis media audio-visual dan dapat mencerminkan suatu objek yang bergerak bersama dengan suara alami atau yang sesuai. Video menyajikan informasi, proses menggambarkan, menjelaskan konsep yang rumit, mengelola keterampilan, meringkas atau memperjanjang waktu, dan membuat perubahan pada sikap. ${ }^{12}$.

Ada beberapa macam video based learning yang di kelompokkan ke dalan beberapa jenis media. Djarmah dan Aswan mengelompokkan media video based learning berdasarkan keberadaannya yaitu menjadi dua macam, yaitu :

a. Media video based learning gerak

Media video based learning gerak adalah salah satu media yang bisa menampilkan dua unsur yang bisa bergerak yaitu unsur suara dan gambar, unsur-unsur tersebut bermula dari satu sumber. Macam-macam media yang meruapakanbagian dalam kelompok ini yaitu:

1) Televisi yang merupakan salah satu sistem elektronik yang menampilkan gambar dan suara secara bersamaan dengan perantara kabel atau ruang.

2) Video yang merupakan salah satu bagian dari media audio visual yang bergerak dengan menampilkan gambar beserta suara dalam keadaan bergerak.

\footnotetext{
${ }^{12}$ Vannisa Aviana Melinda, Nyoman Sudana Degeng, and Dedi Kuswandi. Pengembangan Media Video Pembelajaran IPS Berbasis Virtual Field Trip (Vft) Pada Kelas V SDNU Kratonkencong. JINOTEP (Jurnal Inovasi Dan Teknologi Pembelajaran) Kajian Dan Riset Dalam Teknologi Pembelajaran. Vol 3 (2) 2018. Hlm. 158-164.
} 
3) Film bersuara yang merupakanterdapat beberapa gambar dalam frame, yang manaframe ini dapat diproyeksikan dengan menghubungkan lensa proyektor/LCD dengan listrik secara mekanis sehingga dapat dilihat pada layar berupa gambar dan disertai suara.

\section{b. Media video based learning diam}

Media video based learning diambiasa dinamakan dengan film bingkai suara (sound slide) yang Merupakan salah satu dari media videodengan menampilkan unsur suara dangambar diam, unsur suara dan gambarnya berasal dari sumber yang berbeda. Film bingkai suara (suound slide) merupakan slide yang ditambah dengan suara dari sumber audio yang berbeda, bukan alat audio visual lengkap.

Pembelajaran menggunakan media video pertama kali menggunakan kombinasi antara audio dan film strip untuk pelatihan para tentara waktu perang dunia kedua. Hasilnya, penggunaan film strip mengefisiensi waktu dan membantu meningkatkan kemampuan para tentara tersebut.Pada era 1960an televisi edukasi digunakan sebagai media tambahan di kelas.Para guru juga dihadapkan dengan video peserta didikan mereka sendiri untuk merefleksikan metode pengajaran mereka dan meningkatkan kinerja mereka 13 .

Pada 1980-an, kaset video VHS berarti lompatan kuantum karena menjadi lebih mudah untuk menggunakan video di ruang kelas. Tapi, tetap saja, peserta didik agak pasif dan hanya bisa menonton video.Ini berubah dengan munculnya CD video digital pada pertengahan 1990-an. Guru sekarang dapat menambahkan kontrol multimedia dan alat penilaian dengan menggunakan video di komputer. Dengan demikian, peserta didik menjadi jauh lebih aktif daripada sebelumnya. Pada tahun 2000-an, ruang kelas terhubung ke internet dan video digital interaktif serta konferensi video

\footnotetext{
${ }^{13}$ Ahmed Mohamed Fahmy Yousef, Mohamed Amine Chatti, and Ulrik Schroeder, Video-Based Learning: A Critical Analysis of the Research Published in 2003-2013 and Future Visions (eLmL, 2014).
} 
menjadi mungkin.Sejak itu, teknologi baru seperti smartphone dan tablet dalam kombinasi dengan media sosial seperti YouTube telah berkontribusi pada peningkatan interaksi sosial dan membuatnya lebih mudah untuk mengintegrasikan aplikasi video dalam pendidikan.

Marchionini menyatakan bahwa film dan video sebagai pelengkap yang kuat untuk pengajaran telah dipromosikan menjadi pengajaran di kelas sejak 1950.Video, kombinasi gambar dan suara, menciptakan media yang kuat untuk penjelasan konsep sambil menginstruksikan peserta didik dengan konten yang memberikan banyak indera. Perkembangan maju dalam teknologi komputer dan perangkat lunak memungkinkan penggunaan visualisasi dinamis untuk menggambarkan proses atau konsep kognitif $\operatorname{abstrak}^{14}$

Dalam beberapa tahun terakhir, publikasi VBL telah meningkat untuk membahas bagaimana VBL dapat memfasilitasi pembelajaran dan meningkatkan hasil belajar serta kinerja guru.dengan demikian, ada kebutuhan untuk mengumpulkan penelitian yang ada, mendokumentasikan manfaat video dalam meningkatkan pembelajaran, dan mengeksplorasi desain dan metode pengajaran di lingkungan VBL.

Sebagai tren media pembelajaran, sejumlah besar akademisi publikasi telah menyelidiki dan menganalisis VBL dari perspektif yang berbeda. Yousef melakukan peer review terhadap 76 makalah melalui jurnal dan database akademik yang terbit dalam kurun waktu 2003 sampai 2014 15. Pendekatan pemetaan kognitif digunakan untuk memetakan penelitian yang dilakukan pada VBL menjadi empat dimensi utama yaitu, efektivitas, metode pengajaran, desain, dan refleksi. Sebagian besar studi VBL yang ditinjau masih mengikuti

\footnotetext{
${ }^{14}$ Omer Faruk Vural. The Impact of a Question-Embedded Video-Based Learning Tool on E-Learning. Educational Sciences Journal: Theory and Practice, Vol. 13(2). (2013). p. 1315-1323

${ }^{15}$ Yousef, A. M. F., Chatti, M. A., \& Schroeder, U. (2014).Video-Based Learning: A Critical Analysis of the Research Published in 2003-2013 and Future Visions
} 
pendekatan pembelajaran konvensional di mana guru adalah pusat dari proses pembelajaran. Selain itu, ada fokus pada metode penilaian tradisional, seperti e-Tes dan kuis.

Dengan media pembelajaran berbasis video menyebabkan peserta didik tidak menjadi jenuh dan bersemangat untuk memperhatikan materi. Selain itu, menjadi solusi bagi peserta didik yang mendapatkan materi pertemuan dengan video, peserta didik dapat mempeserta didiki kembali materi tersebut dan mengunduhnya pada tautan yang disediakan kapanpun dan dimanapun. Video juga dapat menjadi solusi dalam penyajian bahan agar tidak monoton 16 . Sejalan dengan Arifin, Hendriyani dkk menyimpulkan bahwa media pembelajaran yang bisa memandu pembelajaran mandiri dan media yang bisa digunakan kapan saja dan dimana saja, salah satunya media pembelajaran yang berbentuk video tutorial merupakan media yang dibutuhkan oleh para peserta didik ${ }^{17}$.

media teknologi informasi dan komunikasi (TIK) yang memungkinkan untuk diakses oleh komunitas yang lebih luas dan paling populer adalah media video. Penggunaan video dalam proses pembelajaran perlu dirancang dan direncanakan dengan baik sehingga media pembelajaran efektif untuk digunakan. Penggunaan media pembelajaran yang tepat dalam proses belajar mengajar di kelas dapat memberikan kenyamanan bagi guru dan peserta didik. Media ini tepat diguanakan bagi peserta didik yang lemah dan lambat dalam menerima konten yang disajikan dengan teks atau disajikan secara verbal. 18

\footnotetext{
${ }^{16}$ Rita Wahyuni Arifin, 'Media Pembelajaran Berbasis Video Animasi Pada Mata Kuliah Logika Dan Algoritma 1', Bina Insani ICT Journal, 4.1 (2017). Hlm. 83-94.

${ }^{17}$ Yeka Hendriyani, Vera Irma Delianti, and Lativa Mursyida. Analisis Kebutuhan Pengembangan Media Pembelajaran Berbasis Video Tutorial. Jurnal Teknologi Informasi Dan Pendidikan Vol. 11 (2) 2018. Hlm. 85-88.

${ }^{18}$ Vannisa Aviana Melinda, Nyoman Sudana Degeng, and Dedi Kuswandi. Pengembangan Media Video Pembelajaran Ips Berbasis Virtual Field Trip. JINOTEP (Jurnal Inovasi Dan Teknologi Pembelajaran). Vol 3 (2) 2018. Hlm. 158-164.
} 
Video merupakan salah satu media pembelajaran yang berfungsi sebagai sarana pemahaman dan pengalaman belajar, jika terdapat di satu sisi untuk tidak memungkinkan berada dalam lingkup yang nyata, media video sebagai sarana penyampaian yang efektif digunakan di era revolusi industri 4.0. Tujuan dari video bagi peserta didik dan guru terdapat kesesuaian untuk menghantar pembelajaran dapat bekerja secara efektif dan efisien. Bagi peserta didik, pembelajaran berbasis video akan menghasilkan gambaran dan pemahaman dari suatu materi pembelajaran dengan bantuan audio dan visual secara nyata dan animasi. Bagi guru, pengunaan video sebagai sarana penyampaian materi dalam pembelajaran dapat membantu peserta didik untuk mengembangkan kemampuan berfikir peserta didik atau sebagai sarana mengembangkan keterampilan berbahasa peserta didik, baik dari segi istima' untuk memahami pelafalan kata, dari segi qira'ah penambahan wawasan yang objektif, dari segi kalam dan kitabah sebagai ketrampilan produksi dapat menjadikan sarana berkomunikasi baik secara verbal maupun tulisan.

Dari berbagai tujuan video sebagai media pembelajaran, ada pula manfaat dari media video untuk menunjang proses pembelajaran baik digunakan dalam kelas maupun luar kelas, video dapat diputar secara berulang-ulang sesuai keinginan peserta didik dan guru, video dapat memanipulasi waktu dan ruang. Pemutaran video bisa menggunakan proyektor, komputer, smartphone, ketiga alat tersebut berguna untuk memutarkan video yang berisi materi peserta didikan.

Media video sering digunakan guru dalam mengembangkan materi peserta didikan agar peserta didik tidak merasa bosan, mudah dimengerti, dan dapat memotivasi peserta didik untuk pembelajaran yang efektif dan efisien. Langkah penggunaan video sebagai media pembelajaran, yaitu :

1)Persiapan baik guru maupun peserta didik, persiapan guru : mempersiapkan video sesuai tujuan dan materi pembelajaran, Persiapan 
peserta didik: mengelola kelas dengan mengatur penempatan peserta didik sesuai intruksi yang diinginkan,

2)Penyajian, peserta didik harap memahami video sebagai penunjang materi yang telah di sampaikan

3)Evaluasi, tanya-jawab dari materi yang telah di sampaikan sebagai penilaian akhir keefektivitas penggunaan media video dalam pembelajaran.

Adapun penyusunan sistem pembelajaran berbasis video terdiri dari tiga tahapan, diantaranya : pertama Pra produksi, Mengidentifikasi masalah, Naskah dan Pembuatan storyboard, kedua Produksi , Perekaman baik berupa audio ataupun visual , ketiga Pasca produksi , Editing video dan Finalisasi ${ }^{19}$.

Video based learning sebagai salah satu media yang tepat digunakan di era milenial sekarang ini, karena tiga alasan : Dapat memotivasi peserta didik dan menciptakan lingkungan yang menyenangkan tanpa mengenal waktu dan ruang, Peserta didik dapat aktif dalam mengembangkan ketrampilan dalam berkomunikasi dari video, Memudahkan peserta didik dalam memahami suatu materi. Sedangkan Video based learning memberikan tiga stimulus penting dalam pembelajaran, yaitukoginitif, afektif dan psikomotorik. Pembelajaran yang mengembangkan emosi dapat dihasilkan dengan berbagai pengaruh dalam perkembangkan intelektual untuk memproses hasil pengetahuan dan pengalaman yang telah diketahui melalui video, sehingga perilaku yang dihasilkan dari video dapat mempengaruhi pengetahuan dalam interaksi sosial dengan lingkungan sekitarnya ${ }^{20}$.

Media video memiliki kelebihan dan kekurangan dalam penggunaannya, seperti yang telah dikemukaan oleh Kustandi dan Bambang, bahwa kelebihan

${ }^{19}$ Muhammad Aziz Fauzan and Dwi Rahdiyanta Pengembangan Media Pembelajaran Berbasis Video pada Teori Pemesinan Frais. Jurnal Dinamika Vokasional Teknik Mesin. Vol 2 (2) 2017. DOI. 10.21831/dinamika.v2i2.15994. Hlm. 82

${ }^{20}$ Robet. Pembuatan Materi Belajar Dengan Pendekatan Video-Based Learning. Jurnal Time. Vol 2 (2). 2013. Hlm. 39-41. 
dari video based learning, diantaranya : peserta didik akan mudah menangkap materi, terdapat pengalaman nyata tanpa membutuhkan ilustrasi yang abstrak, peserta didik tidak merasa jenuh dalam menerima materi karena pembawaan isi yang berupa audio dan visual. Adapun kekurangannya yaitu : pemutaran video membutuhkan peralatan elektronik bisa berupa komputer, LCD dan lain-lain 21.

Selain kelebihan dan kekurangan dalam video based learning, adapula dari segi jenis medianya baik itu televisi, film/ video dan film bingkai. Kelebihan dari jenis televisi, yaitu : dapat menunjukkan dunia nyata di dalam kelas, peserta didik dapat memahami materi secara virtual dan visual. Sedangkan kekurangannya yaitu : pemutarannya berjalan terus tanpa ada jeda yang dapat diatur oleh guru dan peserta didik, tayangan yang terdapat dalam televisi tidak dapat dirubah, dan layar televisi tidak bisa menjangkau semua peserta didik dalam lingkup kelas yang besar.

Kelebihan dari film dan video berbeda dengan televisi diantaranya : pemutarannya bisa diulang-ulang sesuai kebutuhan guru dan peserta didik, film dan video dapat ditunjukkan dalam lingkup yang besar dengan menggunakan alat proyektor/LCD. Sedangkan kekurangan dalam film dan video adalah : pembuatannya memerlukan waktu yang lama dan biaya yang mahal, penyajiannya tidak selalu sesuai dengan materi peserta didikan, kecuali film dan video dibuat atau dirancang oleh guru sesuai dengan isi materi.

Film bingkai suara juga terdapat kelebihan dan kekurangandidalamnya, kelebihan dari film bingkai suara yaitu : materi dalam sound slide dapat diubah sesuai kebutuhan, dapat digabungkan dengan rekaman atau suara sebagai penjelasan isi di dalamnya, dan kekurangannya yaitu : pemaparan isi layar film bingkai suara tidak bergerak sehingga tidak semenarik televisi dan

\footnotetext{
${ }^{21}$ Cecep Kustandi dan Bambang Sutjipto, Media Pembelajaran Manual Dan Digital. (Jakarta: Ghalia Indonesia, 2012).
} 
film, pembuatannya lebih sulit dibandingkan media gambar karna memiliki beberapa tahapan dalam proses pembuatannya(Azhar Arsyad, 2014 : 48-53). Berdasarkan penjelasan dari kelebihan dan kekurangan diatas, maka penggunaan jenis media video bisa disesuaikan dengan kebutuhan guru dan peserta didik, sehingga dapat terealisasikan sebagai sarana komunikasi antara guru dan peserta didik yang inovatif dan efektif.

\section{Kesimpulan}

Revolusi industri berkembang sangat pesat, sehingga perubahan dari era sebelumnya menuju era Revolusi industri 4.0 terdapat inovasi yang sangat ketat untuk perkembangan pendidikan, sehingga para pendidik berupaya mengembangkan sistem pembelajaran yang inovatif dan efektif yang dapat di gunakan dalam pendidikan di indonesia.

Salah satu sistem pendidikan yang merupakan bagian dari proses pembelajaran yaitu media pembelajaran, dalam dunia pendidikan media merupakan sarana komunikasi bagi pendidik dan peserta didik yang mana di dalam nya terdapat interaksi aktif antara keduanya, dalam media pembelajaran di era 4.0 terdapat karaktersitik yang menunjukkan perkembangan suatu media dalam pembelajaran, yaitu Internet of Things, Big data, Argemented Reality dan lain-lain.

Media pembelajaran di era 4.0 bukannya menggantikan media yang dulu atau konvensional menjadikan yang baru namun dalam hal ini media pembelajaran di era 4.0 merupakan perkembangan dari media konvensional, seperti halnya media video yang berupa televisi dan film/video. media video telah ada sejak dahulu, namun media ini masih aktif digunakan di era digital dengan penggunaan yang inovatif dan menarik para peserta didik. Pembelajaran yang berbasis video atau dikenal dengan video based learning, dapat digunakan dalam lingkup pembelajaran bahasa Arab, bahasa Arab yang merupakan bahasa Asing dan pelajaran yang sulit diterima bagi peserta didik, untuk memudahkan 
pembelajarannya, media video hadir dalam pembelajaran bahasa Arab sebagai upaya peserta didik dapat belajar aktif, dikarenakan video terdapat beberapa bentuk yang dapat diambil manfaatnya diantaranya: memudahkan peserta didik dalam memahami materi dengan program video yang dapat diputar berulangulang, video dapat digunakan ketika pendidik terdapat kendala dan mengharuskan pembelajaran dapat berlangsung sesuai pembelajaran, media video dapat digunakan bagi pendidik dan peserta didik ketika membutuhkan native speaker untuk memahami bahasa Arab secara nyata dengan memahami culture penggunaan bahasa Arab.

Dalam hal ini video merupakan media pembelajaran yang tren digunakan di era revolusi industri 4.0, media yang telah sering digunakan dalam pembelajaran baik dalam lingkup besar maupun kecil dan memungkinkan di putar kapanpun ketika membutuhkan materi, pembelajaran yang menggunakan video seperti halnya kegiatan seminar, diskusi, workshop, Yang mana penggunaan video based learning tidak memiliki batasan waktu dan tempat, bisa digunakan secara kondisional yang telah ditetapkan pemateri atau pendidik dalam penyampaian isi yang terkandung didalamnya.

\section{Daftar Rujukan}

Arifin, Rita Wahyuni. (2017). Media Pembelajaran Berbasis Video Animasi Pada Mata Kuliah Logika Dan Algoritma 1. Bina Insani ICT Journal, Vol 4 (1) 2017 Arsyad, Azhar. (2014). Media Pembelajaran. Jakarta: PT. Raja Grafindo Persada. Djamarah, Syaiful Bahri dan Aswan Zain. (2010). Strategi Belajar Mengajar. Jakarta: PT Rineka Cipta

Fauzan, Muhammad Aziz, and Dwi Rahdiyanta. (2017). Pengembangan Media Pembelajaran Berbasis Video pada Teori Pemesinan Frais. Jurnal Dinamika Vokasional Teknik Msein. Vol 2 (2) 2017 
Hendriyani, Yeka, Vera Irma Delianti, and Lativa Mursyida. (2018). Analisis Kebutuhan Pengembangan Media Pembelajaran Berbasis Video Tutorial. Jurnal Teknologi Informasi Dan Pendidikan. Vol. 11 (2) 2018

Joenaidy, Abdul Muis. (2019). Konsep Dan Strategi Pembelajaran Di Era Revolusi Industri 4.0. Yogyakarta: Laksana

Kustandi, Cecep dan Bambang Sutjipto. (2012). Media Pembelajaran Manual Dan Digital . Ghalia Indonesia

Martikasari, Kurnia. (2019). Kahoot: Media Pembelajaran Interaktif Dalam Era Revolusi Industri 4.0. Makalah dipresentasikan dalam Seminar Nasional FKIP

Melinda, Vannisa Aviana, Nyoman Sudana Degeng, and Dedi Kuswandi. (2018). Pengembangan Media Video Pembelajaran Ips Berbasis Virtual Field Trip (Vft) Pada Kelas V Sdnu Kratonkencong. JINOTEP (Jurnal Inovasi Dan Teknologi Pembelajaran) Kajian Dan Riset Dalam Teknologi Pembelajaran. Vol 3 (2) 2018

Nusantara, Toto. (2018). Desain Pembelajaran 4.0. Makalah dipresentasikan dan dipublished pada Prosiding Seminar Nasional Lembaga Penelitian Dan Pendidikan (LPP) Mandala.

Olla, Kevin. (2019). Era Revolusi Industri 4.0 : Semua Hal Yang Perlu Kamu Ketahui. Blog Jagoan Hosting / Tutorial Website \& Web Hosting Indonesia. Diakses tanggal 20 Mei 2020 pada https://www.jagoanhosting.com

Pardede, Parlindungan. (2020). Menjadi Guru "Zaman Now" dan Cara Pembelajaran Siswa Memasuki Era Industri 4.0. Makalah dipresentasikan dalam Seminar Nasional FKIP

Robet. (2013). Pembuatan Materi Belajar Dengan Pendekatan Video-Based Learning. Jurnal Time. Vol 2 (2). 2013

Siregar, Eka Ramadhani. (2018). Multimedia Pembelajaran Dalam Era Revolusi Industri 4.0. Diakses tanggal 16 Mei 2020 pada http://catatankimmunika.blogspot.com 
Vural, Omer Faruk. (2013). The Impact of a Question-Embedded Video-Based Learning Tool on E-Learning. Educational Sciences Journal: Theory and Practice, Vol. 13(2) 2013

Warohidah, Annisa' Rofifah, and Anggun Badu Kusuma. (2019). Perkembangan Era Revolusi Industri 4.0 Dalam Pembelajaran Matematika. Vol. 5 (1) 2019

Yousef, Ahmed Mohamed Fahmy, Mohamed Amine Chatti, and Ulrik Schroeder. (2014). The State of Video-Based Learning: A Review and Future Perspectives. Int. J. Adv. Life Sci. Vol. 6 (3) 2014

Yousef, A. M. F., Chatti, M. A., \& Schroeder, U. (2014).Video-Based Learning: A Critical Analysis of the Research Published in 2003-2013 and Future Visions

Yuniani, Armelia, Dwi Irma Ardianti, and Wal Asri Rahmadani.(2019). Era Revolusi Industri 4.0 : Peran Media Sosial Dalam Proses Pembelajaran Fisika di SMA. Gravitasi: Jurnal Pendidikan Fisika dan Sains. Vol 2 (1) 2019 